\title{
Potensi Suplementasi Nira Aren (Arenga pinnata Merr.)Terhadap Performa Ayam Broiler
}

\author{
Luky Wahyu Sipahutar dan Khairani
}

Dosen Program Studi PeternakanFakultas Peternakan, Universitas Muhammadiyah Tapanuli Selatan e-mail: luky.wahyu@um-tapsel.ac.id ${ }^{1}$ khairani@um-tapsel.ac.id ${ }^{2}$

\begin{abstract}
Abstrak
Penelitian ini bertujuan untuk melihat efek penambahan nira aren yang disuplementasikan dalam air minum terhadap performa ayam broiler.Digunakan sebanyak 100 ekor DOC strainCP 707 yang dipelihara selama 32 hari. Rancangan yang digunakan merupakan rancangan acak lengkap dengan 5 perlakuan dan 4 ulangan (setiap ulangan terdiri dari 5 ekor ayam). Perlakuan suplementasi nira aren dalam air minum terdiri dari P1 (Ransum Basal + Air minum dengan suplementasi nira aren 0\%), P2(Ransum Basal + Air minum dengan suplementasi nira aren 5\%), P3 (Ransum Basal + Air minum dengan suplementasi nira aren 10\%), P4 (Ransum Basal + Air minum dengan suplementasi nira aren 15\%), P5 (Ransum Basal + Air minum dengan suplementasi nira aren 20\%). Variabel yang diamati adalah performaayam (konsumsi pakan, pertambahan bobot badan, konversi ransum). Hasil penelitian menunjukkan bahwa suplementasi nira aren pada air minum berbeda nyata $(\mathrm{P}<0,05)$ meningkatkan bobot badan dan menurunkan konversi ransum. Kesimpulan penelitian ini bahwa suplementasi nira aren pada air minum dapat meningkatkan performa ayam broiler.
\end{abstract}

Kata kunci:Ayam broiler, Nira aren, Performa

\begin{abstract}
The research aims was to know the effect supplementation of nira aren in driking water on performance broiler. A total of 100 DOC of CP strain were used, the observation was conducted for 32 day. Designs were a completely randomized design with five observation and four replications (5 birds each). The treatments consisted of P1(control diet), $P 2$ (control diet $+5 \%$ supplementation of nira aren on driking water), P3 (control diet $+10 \%$ supplementation of nira aren on driking water), P4 (control diet $+15 \%$ supplementation of nira aren on driking water), P5 (control diet $+20 \%$ supplementation of nira aren on driking water). The variabel observation was performance (feed consumption, body weight, feed conversion ratio). The result showed that supplementation of nira aren on driking water produced significantly $(P<0,05)$ increased body weight and decreased feed conversion ratio compared to those without nira aren supplementation. The concluded that supplementation of nira aren on drinking water increases performance of broiler.
\end{abstract}

Keyword: Broiler, Nira aren, Performance

\section{PENDAHULUAN}

Pengembangan ilmu pengetahuan dan teknologi bertujuan menemukan berbagai solusi dari persoalan di masyarakat.Dalam dunia peternakan aspek ketersediaan dan efisiensi menjadi tolak ukur dimasyarakat dalam memilih suatu terapan ilmu pengetahuan dan teknologi tersebut yang dapat membantu meningkatkan pendapantan masyarakat.Nira aren adalah salah satu potensi yang dapat di terapkan dalam dunia peternakan karena ketersediaan bahan dan mudah didapat.Masyarakat di wilayah Tapanuli khususnya Tabagsel (Tapanuli Bagian Selatan) sangat mengenal nira aren. 
Nira Aren merupakan cairan yang disadap dari pohon aren yang banyak dimanfaatkan semenjak dahulu sebagai bahan baku pembuatan gula merah (Batubara et al., 2014).

Pemanfaatan tanaman aren sudah berlangsung lama, tetapi lambat berkembang menjadi komoditas meskipun peluang pengembangan aren sangat luas dan mengingat penyebaran tanaman aren ada disetiap daerah di Indonesia.Menurut Hengky (2012) strategi pengembangan industri aren kedepannya dapat difokuskan untuk energi terbaru dan ketahanan pangan.Untuk mendukung ketahanan pangan, khususnya melalui bidang peternakan, komoditi aren masih belum dikembangkan baik buah, daun, maupun nira aren.Beberapa laporan menyebutkan, masyarakat dibeberapa wilayah di Indonesia telah memanfaatkan nira aren di bidang peternakan baik dalam produk mentah maupun bentuk komersil seperti gula merah yang digunakan sebagai ramuan tradisional pada ternak.Seperti masyarakat Using di Kabupaten Jember menganggap penggunaan nira aren mampu meningkatkan kesehatan ternak, menambah nafsu makan, memelihara kelahiran, dan sebagai asupan nutrisi untuk keperluan penggemukan (Kaunang, 2015). Nira aren mengandung beberapa zat yang berguna bagi unggas diantaranya Karbohidrat 11,18\%, Protein 0,28\%, Lemak kasar 0,01\%, Kalsium (Ca) 0,06\%, Posfor (P2O5) 0,07\%, Asam Asborkanat 0,01\%, serta air 88, 23\%. (Pontoh, 2007).

Mengingat belum adanya penelitian secara ilmiah dan kurangnya data serta informasi mengenai pemanfaatan nira aren pada ternak, maka perlu adanya suatu penelitian mengenai potensi suplementasi nira aren terhadap performa produksi pada ternak.Dari potensi ketersediaan, mudah didapat, harga yang lebih terjangkau, penggunaan yang efisien, serta kandungan yang terdapat di dalam nira aren, sangat melatar belakangi adanya indikasi potensi penggunaan suplementasi nira aren yang dapat dimanfaatkan dalam dunia peternakan.Khusunya ayam broiler yang masih menjadi primadona sebagai komoditas penting dalam dunia peternakan dan sebagai kebutuhan konsumsi daging dalam upaya pemenuhan gizi asal hewani.Penelitian ini diharapkan dapat menjadi dasar serta data ilmiah penting sebagai acuan terkait respon pemberian air nira aren terhadap performa ayam broiler.

\section{METODE PENELITIAN Materi}

Penelitian ini menggunakan DOC ayam broiler jantan strainCP 707 sebanyak 100ekor. Ternak DOC diperoleh secara komersil dengan rataan bobot badan42gram.Kandang perlakuan yang digunakan adalah kandang litter (sekat koloni) sebanyak 20 unit berkapasitas 5 ekor ayam per unitnya.Masing- masing kandang dilengkapi dengan 1 (satu) unit lampu pijar 60 watt, tempat makan, tempat minum air minum.Peralatan yang digunakan adalah tempat pakan, tempat air minum, timbangan digital, dan thermohygrometer. Bahan pakan yang digunakan terdiri atas: jagung, dedak padi, bungkil kedelai, tepung ikan, minyak sawit, CaCO3 dan garam.

Ransum disusun berdasarkan kebutuhan periode ayam broiler yaitu, periode starterdengan kandungan energi metabolis (EM) sebesar $3050 \mathrm{kkal} / \mathrm{kg}$ dan kandungan protein 22\%, growerkandungan energi metabolis (EM) sebesar 3100 $\mathrm{kkal} / \mathrm{kg}$ dan kandungan protein 20\% dan finisherdengan kandungan energi metabolis sebesar $31500 \mathrm{kkal} / \mathrm{kg}$ dan kandungan protein 18\% (Leeson dan Summers, 2008).

\section{Metode}


Perlakuan yang digunakan adalah penambahan nira aren pada air minum. Formulasi ransum dan konsentrasi suplementasi dari tiap kelompok perlakuan dalam penelitian adalah sebagai berikut :

Adaptasi (2 hari): Ransum komersil + Air minum dengan suplementasi nira aren(pada kelompok perlakuan suplementasi)

P1: Ransum Basal + Air minum dengan suplementasi nira aren $0 \%$

P2: Ransum Basal + Air minum dengan suplementasi nira aren 5\%

P3: Ransum Basal + Air minum dengan suplementasi nira aren $10 \%$

P4: Ransum Basal + Air minum dengan suplementasi nira aren $15 \%$

P5: Ransum Basal + Air minum dengan suplementasi nira aren $20 \%$

Ransum penelitian diberikan 2 kali sehari, pagi sebanyak 40\% dimulai pada jam 07.00 WIB setelah kandang, perlengkapan ransum dan tempat air minum dibersihkan, kemudian sebanyak 60\% pada jam 16.00 WIB. Untuk perlakuan pemberian nira aren melalui air minum dilakukan 3 kali sehari yaitu pada jam 07.00 WIB, 13.00 WIB, dan 21.00 WIB sebanyak 1 liter. Pemeliharaan berlangsung selama 32 hari dan dilakukan pencatatan konsumsi ransum, pertambahan bobot badan, konversi ransum.

\section{Analisis Data}

Rancangan percobaan yang digunakan dalam penelitian ini adalah Rancangan Acak Lengkap (RAL) dengan 5 perlakuan dan 4 ulangan (Steel dan Torrie, 1991). Hasil yang diperoleh dianalisis menggunakan sidik ragam ANOVA (analysis of variance), apabila berbeda nyata $(\mathrm{p}<0.05)$ antar perlakuan, maka dilanjutkan dengan uji Duncan's new multiple range test (DMRT).

\section{HASIL DAN PEMBAHASAN}

\section{Konsumsi Pakan}

Pengaruh perlakuan terhadap konsumsi pakan ayam broiler disajikan pada Tabel 1. Hasil analisis ragam menunjukkan bahwa suplementasi nira aren tidak mempengaruhi konsumsi pakan ayam broiler selama pemeliharaan. Rataan konsumsi ransum yang diperoleh pada penelitian ini berkisar antara 2365,152436,8 gram (Tabel 1). Perbedaan masingmasing perlakuan suplementasi nira aren terhadap konsumsi pakan ayam broiler dapat disebabkan tingginya asupan air minum ayam selama pemeliharan.Hasil suplementasi nira aren dalam air minum berdampak pada rendahnya daya konsumsi ransum oleh ayam. Dari rataan konsumsi pakan (Tabel 1) terlihat bahwa kelompok perlakuan tanpa suplementasi nira aren mengkonsumsi ransum sebesar 2436,8 gram/ekor selama pemeliharaan sedangkan pada perlakuan yang diberi suplementasi nira aren lebih rendah.

Nira aren tidak mampu meningkatkan daya konsumsi ayam broiler, namun dengan pemberian nira aren tingkat konsumsi pakan akan lebih rendah dan laju pertambahan bobot badan lebih cepat. Diasumsikan bahwa nira aren dalam air minum mampu melengkapi kandungan yang ada didalam pakan.Daya konsumsi pakan yang rendah disebabkan ayam lebih merasa cepat kenyang karena kandungan karbohidrat yang ada pada nira aren telah mampu memenuhi kebutuhan metabolisnya.Menurut McDonald et al., (2010)Tinggi rendahnya konsumsi ransum berkaitan erat dengan penilaian sensori ternak pada ransum. Bentuk, warna, dan bau merupakan beberapa faktor yang mempengaruhi tingkat palatabilitas ransum

Kandungan karbohidrat yang dubutuhkan dalam pembentukan energi pada air nira sebesar 11,8\% dalam bentuk senyawa glukosa dan fruktosa yang bisa 
langsung diserap ke aliran darah selama pencernaan (Heryani, 2016). Besarnya komposisi yang masuk juga akan menyebabkan rendahnya aktifitas ayam sehingga jumlah energi untuk mendukung pertumbuhan lebih maksimal dibandingkan untuk aktifitas. Hal ini terlihat dari perilaku yang diamati selama penelitian menunjukkan dengan tingkat konsumsi air minum yang tinggi ayam terlihat lebih banyak berbaring dan diam.

Tabel 1. Rataan konsumsi pakan, pertambahan bobot badan, dan konversi pakan

\begin{tabular}{lccccc}
\hline \multirow{2}{*}{ Performa Produksi } & \multicolumn{5}{c}{ Perlakuanpemberian nira aren melalui air minum } \\
\cline { 2 - 6 } & P1 & P2 & P3 & P4 & P5 \\
\hline Konsumsi pakan (gram/ekor) & 2436,8 & 2365,15 & 2398,9 & 2382,8 & 2397,5 \\
Pertambahan bobot badan & $508^{\mathrm{b}}$ & $619,5^{\mathrm{a}}$ & $588^{\mathrm{a}}$ & $650,75^{\mathrm{a}}$ & $647,25^{\mathrm{a}}$ \\
(gram/ekor) & $4,8^{\mathrm{a}}$ & $3,84^{\mathrm{bc}}$ & $4,08^{\mathrm{b}}$ & $3,67^{\mathrm{c}}$ & $3,72^{\mathrm{bc}}$ \\
\hline
\end{tabular}

\section{Pertambahan Bobot Badan}

Pengaruh perlakuan terhadap pertambahan bobot badan disajikan pada Tabel 1. Hasil analisis ragam menunjukkanbahwa suplementasi nira aren menunjukkan pengaruh nyata $(\mathrm{P}<0,05)$ terhadap pertambahan bobot badan ayam broiler. Pengaruh pada masing-masing perlakuan terlihat bahwa kelompok perlakuan yang diberi nira aren dalam berbagai konsentrasi menunjukkan hasil yang berbeda terhadap perlakuan tanpa suplementasi nira aren. Namun tidak terdapat perbedan pada masing-masing kelompok perlakuan nira aren. Dari hasil penelitian diketahui bahwa pertambahan bobot badan tertinggi yaitu pada kelompok P4 (20\%) sebesar 650,75gram. Seiring rendahnya konsentrasi yang diberikan, maka pertambahan bobot badan juga rendah, sebaliknya semakin tinggi konsentrasi nira aren yang disuplementasikan akan berpengaruh terhadap laju pertumbuhan bobot badan.

$$
\text { Adanya hubungan antara }
$$
konsentrasi nira aren dan pertambahan bobot badan dapat disebabkan terpenuhinya kebutuhan energi yang merupakan prioritas utama pertumbuhan.Kandungan karbohidrat yang dimiliki nira aren dapat dimanfaatkan ayam broiler sebagai sumber energi. Karbohidrat yang ada pada nira bila dikonsumsi akan terkonveksi menjadi glukosa dan fruktosa. Karbohidrat dalam bentuk glukosa sangat berperan penting sebagai molekul bagi pembentukan energi tubuh (Irawan, 2007).Hasil penelitian yang dilakukan Aryanti et al., (2013) dengan pemberian air gula merah dalam air minum juga memberikan berpengaruh dalam meningkatkan pertambahan bobot ayam kampung pedaging.

\section{Konversi Ransum}

Pengaruh perlakuan terhadap konversi ransum ayam broiler disajikan pada Tabel 1. Hasil analisis ragam menunjukkan bahwa suplementasi nira aren memberikan pengaruh yang nyata $(\mathrm{P}<0,05)$ terhadap konversi ransum ayam broiler selama pemeliharaan. Pengaruh pada masing-masing perlakuan terlihat bahwa kelompok perlakuan yang diberi nira aren dalam berbagai konsentrasi menunjukkan hasil yang berbeda. Antar 
perlakuan suplementasi nira aren $0 \%$ dan $10 \%$ berbeda sangat nyata, rataan konversi ransum masing-masing 4,80 : 4,08. Tidak ada perbedaan pengaruh perlakuan pada kelompok P3 (15\%) terhadap kelompok P2 (5\%) dan P5 (20\%), namun pada konsentrasi 15\% (P4) panurunan konversi ransung sangat berbeda nyata dibandingkan kelom 0\% dan 10\%.

Secara umum konversi ransum antara kelompok ayam broiler yang disuplementasikan nira aren dengan perlakuan tanpa pemberian suplementasi nira aren menunjukkan adanya perbedaan.Kelompok ayam broiler yang disuplementasikan nira aren memiliki konversi ransum (FCR) yang lebih rendah dibandingkan perlakuan kontrol sampai dengan periode akhir pemeliharaan.Nira aren mampu menurunkan angka konversi ransum ayam broiler selama pemeliharaan.Jika nilai konversi pakan besar, maka dapat diartikan konsumsi pakan kurang efisien.Semakin kecil angka konversi ransum yang dihasilkan berarti semakin baik konsumsi pakan dan pertumbuhannya (Yunilas, 2005).Faktor yang mempengaruhi konversi ransum adalah berat badan, kandungan energi dan nutrien dalam ransum, produksi telur, dan temperatur (Leeson dan Summers, 2008).

\section{KESIMPULAN}

Suplementasi nira aren berdampak positif terhadap ayam broiler, dimana selama pemeliharaan efisiensi dalam konsumsi pakan, peningkatan pertambahan bobot badan, dan menghasilkan angka FCR yang rendah.

\section{DAFTAR PUSTAKA}

Aryanti, F., M.B. Aji, dan N. Budiono. 2013. Pengaruh Pemberian Air Gula Merah terhadap Performans Ayam Kampung Pedaging. Jurnal Sain Veteriner, 31 (2): 156-165.

Batubara, E.M., Rujiman, dan Rahmanta. 2014. Analisis Faktor-Faktor yang Memengaruhi Pendapatan Petani Gula Aren dan Pengembangannya pada Lahan Marginal di Kabupaten Tapanuli Selatan. Jurnal Ekonomi, 17 (4):162-173.

Heryani. H. 2016. Keutamaan Gula Aren dan Strategi Pengembangan Produk. Lambung Mangkurat University Pres, Banjarmasin.

Irawan, M.A. 2007. Glukosa dan MetabolismeEnergi. Sport Science Brief. Polton SportsScience and Performance Lab. 1 (06).

Kaunang, S.R. 2015. "Etnobotani (Pemanfaatan Tumbuhan Secara Tradisional) dalam Pengobatan Hewan Ternak oleh Masyarakat Using di Kabupaten Banyuwangi”.Skripsi. Jember: Program Studi Pendidikan Biologi Fakultas Keguruan Ilmu Pendidikan Universitas Jember.

Leeson, S., dan J.D. Summers. 2008. Commercial Poultry Nutrition (3rded), Department of Animal and Poultry Science University of Guelph, Guelph: University Books.

McDonald, P., R. A. Edwards, J. F. D. Greenhalgh, C. A. Morgan, L. A Sinclair,\& R. G. Wilkinson. 2010. Animal Nutrition. 7th ed. Prentice Hall., New York.

Pontoh, J. 2007. Analisa Komponen Kimia dalam Gula danNira Aren, Sulawesi 
Utara, Tomohon: Laporan pada Yayasan Masarang.

Steel, R.G.D., dan J.H. Torrie. 1991.Prinsip dan Prosedur Statistika suatu Pendekatan Biometrik (Edisi ketiga). Terjemahan $\mathrm{M}$. Syah.Jakarta: Gramedia Pustaka Utama.

Yunilas.2005. Performa Ayam Broiler yang Diberi Berbagai Tingkat Protein Hewani Dalam Ransum, Jurnal agribisnis peternakan, 1 (1). 